\author{
Amantius Akimjak \\ ORCID: 0000-0003-1295-3274 \\ Katolicki Uniwersytet w Rużomberku \\ Wydział Teologiczny \\ Koszyce, Słowacja
}

\title{
Muzikoterapia hudba ako rapeuticky prostriedok
}

\author{
Innovative methods in music teaching
}

https://doi.org/10.34739/sn.2019.19.16

\begin{abstract}
Music teaching is a compulsory subject in the curriculum of a basic art school. For most pupils, however, this subject is not attractive. It is up to the teacher to raise the interest in pupils by appropriate didactic procedures and to point out the necessity of musical learning to develop musical abilities of the pupils.

Keywords: art school, musical instruction, didactic game, rhythm, tact, melody

Zhrnutie: Výchovno-vzdelávací proces prešiel v 20. storočí zásadnými zmenami a vývojom. Už pri letmom pohl'ade na množstvo alternatív didaktických postupov a vyučovacích metód vidíme, že žiaden akokolvek prepracovaný a dokonalý systém nie je univerzálny a jedine správny. Hudba a predmet hudobná náuka je pre žiaka v mladšom školskom veku predovšetkým hrou, v ktorej môže uplatňovat' svoj poznávací a objavitel'ský inštinkt. Vyjadruje ňou svoje pocity, zážitky, svoj vnútorný svet a spätne hudba obohacuje jeho osobnost'. Pomáha mu vytvárat' životnú energiu a pocit radosti. Hudobné hry sú preto vel'mi odporúčanou činnostou. Môžeme ich realizovat' v akejkolvek etape vy-učovacej hodiny i v rámci všetkých hudobných činností.
\end{abstract}

Klúčové slová: umelecká škola, hudobná výučba, didaktická hra, rytmus, takt, melódia

\section{Úvod}

Výchovno-vzdelávací proces prešiel v 20. storočí zásadnými zmenami a vývojom. Už pri letmom pohl'ade na množstvo alternatív didaktických postupov a vyučovacích metód vidíme, že žiaden akokolvek prepracovaný a dokonalý systém nie je univerzálny a jedine správny. Hudba a predmet hudobná náuka je pre žiaka v mladšom školskom veku predovšetkým hrou, 
v ktorej môže uplatňovat' svoj poznávací a objavitel'ský inštinkt. Vyjadruje ňou svoje pocity, zážitky, svoj vnútorný svet a spätne hudba obohacuje jeho osobnost'. Pomáha mu vytvárat' životnú energiu a pocit radosti. Hudobné hry sú preto vel'mi odporúčanou činnostou. Môžeme ich realizovat' $v$ akejkolvek etape vyučovacej hodiny i v rámci všetkých hudobných činností.

\section{Hra, pojem a význam hry}

Proces učenia žiakov v základnej umeleckej škole vzhl'adom k vekovým a individuálnym osobitostiam je vel'mi zložitý. Učenie by malo byt' organizované tak, aby vystupovalo ako slobodná forma aktivity žiakov, aby ich upútalo, zaujalo. Práve z tejto skutočnosti by sme mali vychádzat', že sa učíme, i ked' sa hráme. V súlade so vzdelávacími ciel'mi hodiny by sme sa mali častejšie zamýšlat' nad zarad'ovaním hier určených k vzdelávacím účelom.

Šimčík [2001, s. 8] považuje hru za jednu zo základných foriem l'udskej činnosti (hra, učenie, práca). Človek sa s hrou stretáva po celý život, no jej postavenie závisí od vekových zvláštností. Človek sa najprv slobodne hrá a neskôr si uvedomuje, že jeho hra môže aj niečo vyjadrovat'. Najdôležitejšie postavenie má v období predškolského veku, kde je hlavnou činnostou detí. V období mladšieho školského veku sa výrazne mení a hlavnou náplňou sa stáva učenie. Hra je najčastejšie chápaná ako zábava. A zábava je predovšetkým to, čo dokáže zaujat', napínat', udržiavat' pozornost' a spravidla vyvolávat' i prijemné rozpoloženie ducha. No hra je nielen zábavou a rozptýlením, ale aj tvorbou a rozvijaním fantázie. V Ottovom „Slovníku náučnom“ [1988, s. 17] je definovaná hra ako: „,... opak práce. Nutnost' a viazanost' samovol'ne uložená, alebo vynútená, aká charakterizuje prácu, mení sa pri hre vo svoj opak“.

Laubert, Laubertová [1987, s. 15] sa vyjadrujú o hre nasledovne: Hra je spravidla zábavné a často i napínavé a sútaživé znázornenie života, alebo cvičenie pre uplatnenie $v$ životnom procese, eventuálne hl'adanie správneho riešenia podmienok existencie uplatňovania schopností. Tiež možno súhlasit' s tvrdením, že hra je špecifickým prejavom aktivity dietatáa, diet́a sa ňou začleňuje do prostredia, hladá si vlastné miesto v spoločnosti, učí sa spolupráci, sútaživosti a podriad'ovaniu sa spoločenským normám. Hra všeobecne rozvíja ludskú tvorivost', fantáziu, prispieva k zlepšovaniu pamäti a vyjadrovaniu detí.

Aby bola hra hrou, t.j. potešenie mysli, musí podla J.A. Komenského spĺn̆at' tieto podmienky: 
- pohyb,

- vlastné rozhodnutie,

- spoločenstvo,

- sútaženie,

- pravidlá,

- jednoduchost',

- príjemné uvol'nenie mysle.

Význam hry môžeme posudzovat' z týchto hl'adísk:

\section{Hra ako hlavná forma organizácie života detí}

V predškolskom období je hra pre deti najbežnejšia činnost'. Prejavuje sa v nej spontánnost', l'ubovôl'a, uspokojuje potreby dietatáa a motivuje ho k formovaniu vlastných postojov. Neskôr sa spontánnost' vytráca a hra plní určitý ciel'.

\section{Hra ako prostriedok výchovno-vzdelávacej práce}

Hra pomáha dosahovat' ciele výchovy a vzdelávania. Známe hry môžeme upravovat tak, aby činnost' detí sledovala nami stanovený ciel', a aby rozvíjala tie schopnosti, ktoré chceme rozvijat'. Pri rozvijaní hudobných schopností využijeme tie vlastnosti, ktoré sú pre deti typické: fantáziu, zvedavost', všímavost' spojenú s radostou z činnosti a napodobňovania, túžbu uplatnit' sa a iné.

\section{Hra ako metóda výchovno-vzdelávacej práce}

Hra ako učebná a motivačná metóda je známa už od čias J.A. Komenského, ktorý povedal: „Metóda, aby vzbudila chut do štúdia, musí byt' po prvé prirodzená. Po druhé, aby už sama metóda privábila mysel', treba ju rozumne oslad'ovat', to jest, aby sa všetky veci, nech sú akokolvek vážne, prednášali domácky a príjemne, totiž vo forme rozhovoru, alebo závodenia v hádankách a napokon v podobenstvách a bájkach" [Komenský, 1953, s. 116-117]. Hra je nevyhnutná pre telesný, psychický rozvoj a socializáciu dietatáa. Dominanciu má pohybová a didaktická hra, ktorá rozvíja poznanie dietatáa, jeho myšlienkové operácie a reč.

\section{Klasifikácia hier}

Hry rozdel'ujeme na dve základné skupiny: prirodzené hry, hry s pravidlami.

Prirodzené hry - diet́a si ich vytvára samo, vyberá si tému, obsah, doplnky, pomôcky a okruh spoluhráčov. Môžeme ich nazývat' aj hry tvorivé. Obsahom sú zážitky, skúsenosti a dojmy detí zo života. Tieto hry delíme na: 

a) tematické - námetové - hry podla námetu,
b) dramatizujúce - hry podla predlohy,
c) konštruktívne - zostrojovanie, konštruovanie.

Hry s pravidlami - sú umelo vytvorené v ustálenej podobe. Delíme ich na:

a) pohybové - pohybová aktivita,

b) didaktické - hry na riešenie rozumových úloh, kde sa spája spontánna detská činnost' s cielavedomou prácou a učením.

Podla Králička (1976, s. 10) rozdel'ujeme hry na:

1) Hry nepodmienené reflexné - inštinktívne hry.

2) Senzomotorické hry-motorické, sluchové, zrakové hry.

3) Hry intelektuálne - funkčné, námetové, napodobivé hry.

4) Hry kolektívne - sútaživé, rodinné a stolové hry.

V. Vondráček rozoznáva tieto typy hier:

- hra s predmetmi, alebo vlastným telom bez účasti intelektu,

- hra s predmetmi, ktoré sú modelom alebo symbolom niečoho, imitáciou, mikrosvetom,

- hra s dočasnými rolami,

- hra športová, kde subjekt vyvíja činnost' podl'a určitých pravidiel,

- hra bojová, kde subjekt hrá proti druhému, alebo je v skupine, ktorá hrá proti druhej skupine s predmetmi a zachováva určité predpísané pravidlá,

- hra divadelná, kde herec predstavuje inú osobu v rámci predpisov autora hry a vžíva sa do nej niekedy až k úplnej identifikácii,

- hry vyjadrujúce to, čím by subjekt chcel bytt.

\section{Didaktická hra, pojem a podstata didaktickej hry}

Každá didaktická hra je nositel'om vzdelávacej a výchovnej funkcie, čo znamená, že didaktická hra detí nielen vzdeláva, učí a rozvíja už naučené hravou formou, ale súčasne aj vychováva. Preto je ideálne spojenie učenia, hry a výchovy $v$ jednotný celok.

Názov didaktická hra pochádza z gréckeho slova „didasko - učím“. Samotný prívlastok didaktický znamená poučný, nám vysvetluje poslanie týchto hier. Hra musí byt' zakomponovaná do vyučovacej hodiny ako jej súčast', čiže sa 
využíva s jasným didaktickým ciel’om, so zrejmým úmyslom, ináč by stratila na význame, znehodnotila by sa jej možnost' využitia, nepriniesla by efektívnost'.

O presnom vymedzení pojmu didaktická hra sa pokúsili autori Průcha, Walterová a Mareš [1990, s. 48] v „Pedagogickom slovníku.“ Vymedzili ju nasledovne: „Didaktická hra je analógia spontánnej činnosti detí, ktorá sleduje didaktické ciele". Môžu sa odohrávat' v učebni, telocvični, na ihrisku, v obci, v prírode. Má svoje pravidlá, vyžaduje priebežné riadenie a záverečné vyhodnotenie. Je určená jednotlivcom a skupinám žiakov, pričom rola pedagogického vedúceho má široké rozpätie od hlavného organizátora až po pozorovatel'a. Prednostou didaktickej hry je jej stimulačný náboj, pretože prebúdza záujem, zvyšuje zaangažovanost' žiakov na prevádzaných činnostiach, podnecuje tvorivost', spontánnost', spoluprácu i sútaživost', núti použivat' poznatky a vedomosti, zapájat' živú skúsenost'. Niektoré didaktické hry sa bližia modelovým situáciám z reálneho života. Didaktická hra je hra s pravidlami, ktorá spĺňa určitý didaktický ciel' a jej základom je poskytnút žiakom určité vedomosti. Hrou je však preto, že žiaka baví samotná činnost', samotný priebeh hry a umožňuje mu prirodzenú aktivitu a uspokojenie svojich potrieb, citov, fantázie a sebarealizácie. Je významnou metódou, dopĺn̆a učivo, pomáha lepšiemu osvojeniu a precvičovaniu učiva. Didaktické hry sú tiež vhodným prostriedkom na zbližovanie učitel'a a žiaka. Dobrý učitel' nevychováva len učením, ale pozná aj detské myslenie, záujmy, schopnosti a tieto postupne rozvíja.

Už za dávnych čias sám J. A. Komenský považoval hru za cvičenie tela a ducha, ktorá je pre diet́a potešením.

\section{Štruktúra didaktickej hry}

Didaktická hra má svoju osobitnú štruktúru, ktorá je dôležitá na dosiahnutie vytýčeného ciel'a. Štruktúru didaktických hier tvorí niekol'ko typických znakov, ktoré sú jej podstatou. Sú to:

- hrová úloha (ciel),

- vlastná hrová činnost',

- pravidlá hry,

- výsledok, záver hry a jej vyhodnotenie.

Hrová úloha vychádza z didaktického ciel'a hry a je nositel'om náučného obsahu hry. Stanovuje ju učitel'. Obyčajne zaznieva už v samotnom názve hry a uvádza deti do úlohy, ktorú majú v hre splnit. Vyvoláva záujem žiakov, aktivizuje ich pozornost' a sprostredkováva poznatky. Dáva didaktickej hre zmysel, 
čo je dôvodom, prečo sa takáto hra zostavuje a využíva. V didaktických hrách sa uplatňujú úlohy, pri plnení ktorých si žiaci osvojujú a upevňujú vedomosti, skúsenosti a návyky. Každá didaktická hra predkladá detom také úlohy, ktorých riešenie $v$ každom prípade vyžaduje určitú intelektuálnu námahu, duševnú prácu.

Vlastná hrová činnost' je najpodstatnejšou častou didaktickej hry. Bez nej by bolo uskutočňovanie ciela iba suchopárnym didaktizovaním a didaktická hra by stratila najsilnejší moment prítažlivosti pre deti. Učitel' využíva hru pre jej didaktickú úlohu, ale žiak ju hrá hlavne pre jej zaujímavú činnost.' Hrová činnost' je práve tým, čo robí hru hrou. Pokladáme ju za motivačný prostriedok vyučovania, lebo ho robí zaujímavejším a pôsobivejším. Hravou činnostou sa dosahuje didaktický ciel' a rieši zadaná úloha. Náučný obsah musí byt' dostatočne vyvážený hrovou činnostou, aby diet́a nevnímalo, že sa učí, aby si poznatky osvojovalo, precvičovalo a upevňovalo skutočne hravým spôsobom. Žiak musí cítit', že sa hrá a nie, že sa učí. Hravý prvok musí navonok dominovat' nad vlastnou úlohou. Hravá činnost' umožňuje zaradit' do vyučovacích hodín aj také úlohy, ktorých plnenie by inak bolo suchopárne a abstraktné. Hrové činnosti sú rozmanité, avšak všetky $v$ záujme úspešnosti musia spĺňat dve základné podmienky:

a) nevyhnutne sa musia podriad'ovat' úlohe a spĺnat tak náučný ciel' hry,

b) musia byt zaujímavé a udržiavat' pozornost' detí od začiatku hry až do konca.

Pravidlá hry sú d’alšou súčastou didaktickej hry, pretože organizujú hravú činnost́ tak, aby sa skutočne zamerala na plnenie danej úlohy. Žiak dostáva presné inštrukcie, ako má v hre postupovat', čo môže a čo nemôže robit'. Pravidlá zabraňujú tomu, aby sa hra vyvijala živelne. Tým, že pravidlá presne organizujú činnost' žiaka, zvyšujú pôvab a prítažlivost' hry. Žiaci sa musia podriadit' pravidlám, a tak sa vychovávajú k disciplíne, pevnej vôli a zodpovednosti za výsledky skupiny. Pravidlo dáva oporné body mysleniu, reči i konaniu. Didaktické pravidlo sa vztahuje na obsah hry a má najčastejšie slovnú podobu. Má byt' stručné, jeho formulácia má byt jasná, presná, zrozumitel'ná. Musí poskytovat' možnost' kontroly a sebakontroly. Aby didaktická hra bola hrou, musia pravidlá zdôrazňovat' niektorý citový prvok (napr. sútaživost' - kto skôr, kto lepšie, kto viac, a. i.). Zložitost' pravidiel má byt' priamo úmerná rozumovej vyspelosti detí. Ak by dodržiavanie pravidiel didaktickej hry kládlo privel'ké 
požiadavky na rozumové a vôlové úsilie detí, hra by bola pre ne náročná, namáhavá a zúčastňovali by sa na nej s nevôlou.

Výsledok, záver a vyhodnotenie hry. Každá činnost' sa končí nejakým výsledkom. Didaktická hra má byt' ukončená vyhlásením výsledku, zhodnotením účasti jednotlivých žiakov, poprípade skupín, družstiev, alebo celej triedy. Ukončenie je kontrolou, ako žiaci splnili úlohu, zachovali pravidlá. Záver hry obyčajne smeruje $k$ celkovému hodnoteniu činnosti žiaka pri hre. Hodnotou výsledku zvyčajne posudzujeme výsledok hry z hladiska oboch zúčastnených strán, a to z hladiska detí a z hladiska učitel'a. Z hladiska detí hodnotíme predovšetkým uspokojenie ich potreby hrat' sa, a v hre realizovat'. Deti v didaktickej hre uplatňujú svoje vedomosti, schopnosti, zručnosti a pocit úspechu im prináša radost', citové a morálne uspokojenie. Pre učitel'a hra je prostriedok, ktorým dosahuje u detí vytýčený ciel', či výsledok zodpovedá didaktickej úlohe. S výsledkom činností úzko súvisí hodnotenie úspešnosti účastníkov hry, či a nakol'ko správne vykonali predpísanú činnost' pri dodržiavaní pravidiel. Je nutné, aby bol výkon žiakov v hre hodnotený čo najpozitívnejšie. Hodnotenie žiakov výrazne ovplyvňuje proces učenia, ich výkon. Pochvala za dobre zvládnutú úlohu sa tak stáva podnecujúcim činitel'om pre intenzívnejšiu a presnejšiu prácu, stáva sa motiváciou. Hodnotenie do značnej miery určuje, ako sa budú prebúdzat' žiakove záujmy o poznávanie a ako si žiak oblúbi daný predmet. Uvedené štyri charakteristické znaky didaktickej hry sú navzájom úzko späté. Iba didaktická hra zladená na takejto štrukturálnej výstavbe môže spĺňat' svoju vzdelávaciu a výchovnú funkciu.

\section{Klasifikácia didaktických hier}

Didaktické hry môžeme rozdel'ovat' do viacerých skupín podla rôznych kritérí.

Podl'a obsahu didaktickej hry môžeme označit hry so zameraním na:

- jazykový rozvoj,

- logicko-matematický rozvoj,

- rozvoj vedeckého poznania,

- rozvoj pohybu,

- rozvoj esteticko-hudobných schopností,

- rozvoj organizačno-riadiacich schopností.

Podl'a toho, čo didaktická hra rozvija, môže ist' o hry:

- senzorické (rozvoj zmyslov),

- na rozvoj pamäti, 
- na rozvoj myslenia,

- na rozvoj komunikácie,

- na rozvoj tvorivosti.

Podl'a toho, v ktorej časti vyučovacieho procesu didaktickú hru využijeme, ide o hry:

- motivačné,

- získavania nových skúseností,

- na upevňovanie znalostí [Zapletal, 1986, s. 34].

Pre hudobnú výchovu je vel'mi významná tá skutočnost', že hra je v psychológii chápaná ako určitá modelová situácia pre diet́a, v ktorej sa dostáva do konkrétnej rolovej pozície. V publikácii „Hudba hrou“ Šimčík [2001, s. 43] klasifikuje hry v hudobnej výchove na základe dominantného zastúpenia tej - ktorej hudobnej aktivity. Dominantné (východiskové) hudobné činnosti (aktivity) sú v zmysle ponímanej interakčnosti akousi „spúštou“ pre d'alšie sprievodné aktivity.

Na základe tohto prístupu sme hry rozdelili do piatich východiskových skupín:

- rytmické hudobné hry,

- vokálno-intonačné a sluchovo analytické hudobné hry,

- inštrumentálne hudobné hry,

- hudobno-pohybové hry,

- hry zamerané na rozvoj hudobnej predstavivosti, fantázie a tvorivosti.

\section{Využitie didaktickej hry}

Didaktické hry určené pre primárne vzdelávanie $v$ základných umeleckých školách môžeme využit v rôznych častiach vyučovacej hodiny (pri opakovaní a upevňovaní učiva, pri precvičovaní vedomostí a návykov, pri zoznamovaní sa s novým učivom), nie však náhodne. $V$ didaktickej hre diet́a spontánne uplatňuje poznávacie aktivity a vzdelávacia činnost' tu prebieha nenásilne. Spravidla ju diet́a vôbec nevníma, ide mu predovšetkým o hru. Učitel' by si mal premysliet', prečo ju zarad'uje a k čomu má na vyučovaní slúžit'.

Didaktická hra má značný vplyv na:
a) kognitivizáciu žiaka,
b) motiváciu a aktivizáciu,
c) emocionalizáciu,
d) socializáciu žiakov,
e) komunikáciu,
f) kreativizáciu,
g) axiologizáciu. 


\section{Uplatnenie didaktickej hry v druhom ročníku základnej umeleckej školy}

Ciel'om hudobnej náuky $v$ 2. ročníku ZUŠ je rozvíjat' hudobnú predstavivost' a pamät'. Rozširovat' piesňový repertoár, upevňovat' správne spevácke návyky. Viest' žiakov k uvedomovaniu si hodnoty a krásy l'udovej piesne, vediet' si vážit' ludovú hudobnú kultúru.

\section{Hra č. 1. Práca s piesňou}

Doplňte správne rytmicky a melodicky noty v piesni „Jedna druhej riekla“, ktoré chýbajú v notovej osnove.

\section{Hra č. 2. Hudobné hádanky}

Žiaci majú vel'mi radi hádanky a ešte radšej ich tvoria. Vyberú si medzi sebou chlapca („Zvedavý Janko“), ktorý sa bude pýtat' (hudobná otázka) a úlohou ostatných je správne odpovedat' (hudobná odpoved'). Zvedavého Janka hrá stále iný žiak a tým vytvára nový variant.

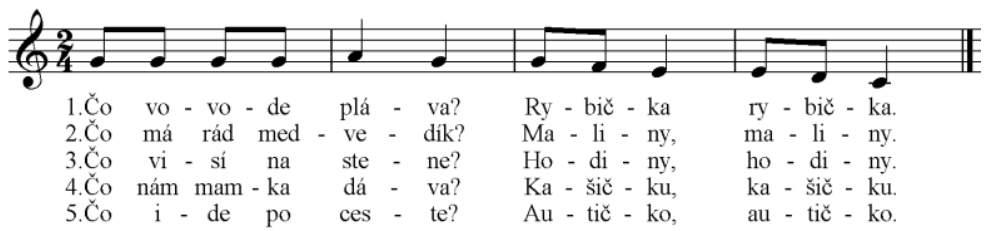

\section{Hra č. 3. Dynamické značky}

Ako motiváciu môžeme zvolit vel'mi jednoduchú detskú hru - hru na ozvenu. Žiaci sa rozdelia na dve skupiny:

- skupina zaspieva melódiu silno,

- skupina urobí ozvenu a zaspieva tú istú melódiu slabo.

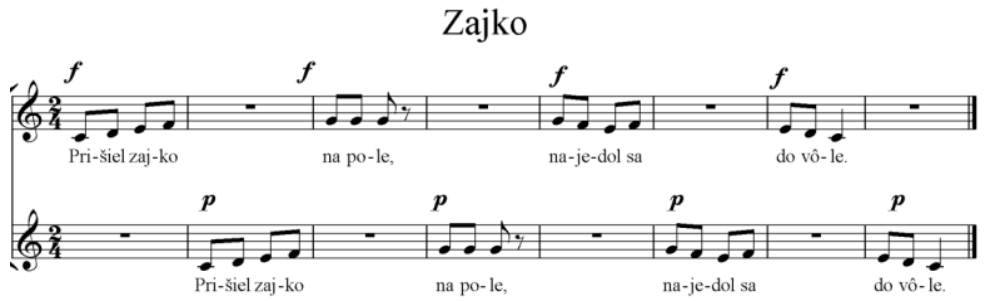




\section{Hra č. 4. Hádanky}

a) Dotkneš sa toho, cengá to, a predsa to nie je zvonček. Čo je to? (Triangel)

b) Opakom svetla je tma. Čo je opakom pianissima? (fortissimo) Čo je opakom acceleranda? (ritartando) Čo je opakom allegra? (andante) Čo je opakom crescenda? (decrescendo)

c) Vianoce sú chvíle štastia a pohody. Čo si spieval pod stromčekom? (koledy)

d) Odpoved' bude celkom istá, ked' sám spevák spieva, je.(sólista)

e) Ženy, muži, všetci spolu spievajú, povedzte mi, ako ludia tento zbor nazývajú? (miešaný zbor)

f) Pol'ovník zbadal jelení paroh, zatrúbil slávnostne na.(lesný roh)

\section{Hra č. 5. Tvorba piesne}

Riekanku zmelodizujte v tónovom rozsahu c1 - a1 v 2/4 takte „Bude zima, bude mráz, kam sa vtáčku, kam schováš? Schovám sa do javora, tam je moja komora".

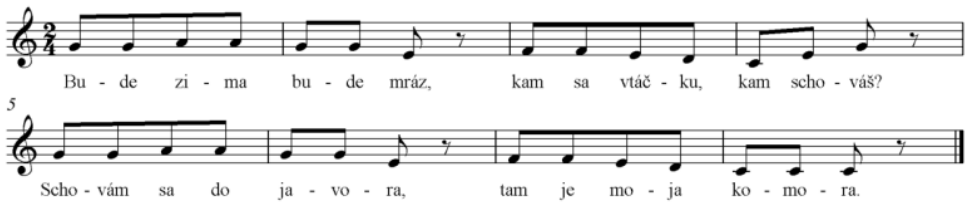

Pieseň je utvorená a my môžeme pracovat' v skupinách.

- skupina: K piesni „Bude zima, bude mráz“ utvorte rytmický sprievod hrou na telo (tlieskanie, plieskanie).

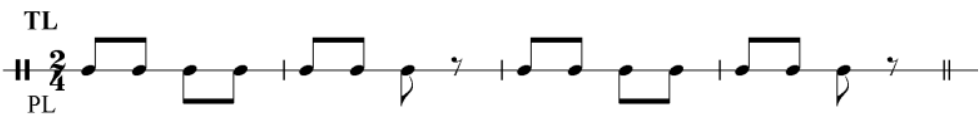

- skupina: Vytvorte vlastný rytmický sprievod s použitím triangla, bubienka a paličiek. 


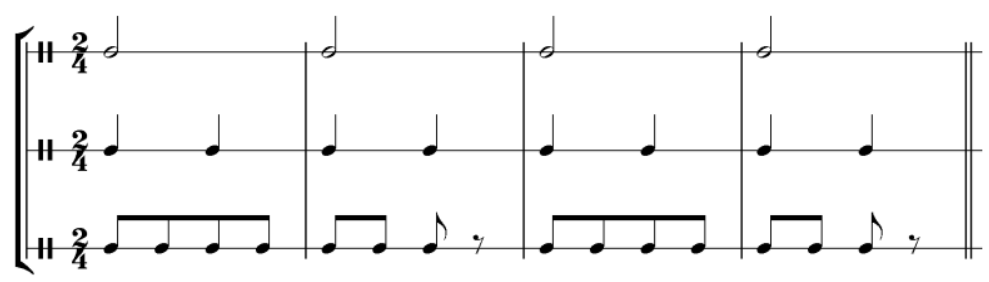

\section{Hra č. 7. Melodizácia rečňovanky}

Učitel' pripraví žiakom rytmus:

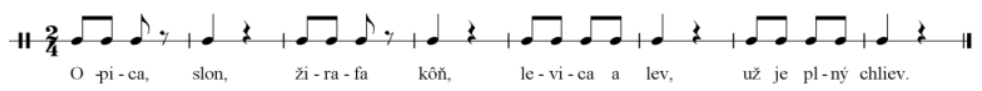

Podl'a tohto rytmu sa pokúsime vytvorit' jednoduchú melódiu, ktorú zaspievame v tempách:

- adagio,

- moderato,

- Allegro.

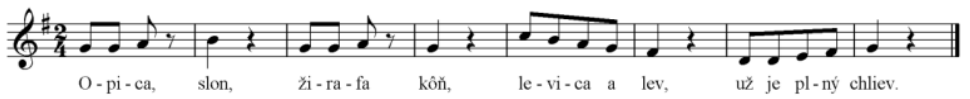

Teraz si melódiu vymyslíte aj vy. Viete ako sa to robí - opakovaním, krokmi, skokmi a všetkým spolu. Aby bola pesnička ešte krajšia, zahráme si $k$ nej sprievod a jeden z vás bude dirigovat. Sprievodnými nástrojmi budú klavír (učitel'), triangel, bubienok, tamburína.

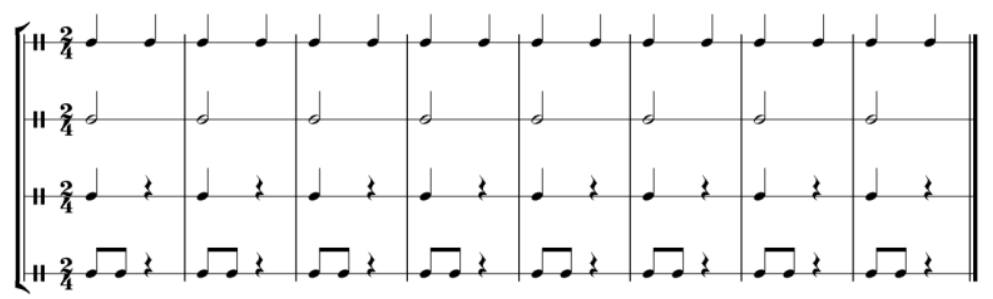

Striedame žiakov v jednotlivých činnostiach a vyhodnotíme, napr.: kto bol najlepším dirigentom, spevákom, hráčom na bubienok, triangel, tamburínu. 


\section{Záver}

Didaktická hra má svoje nezastupitel'né miesto vo vyučovaní hudobnej náuky pri upevňovaní a osvojovaní si hudobných pojmov a zručností dietatáa. Ďalším významným faktorom vyplývajúcim zo skúseností pri využívaní didaktických hudobných hier $v$ pedagogickej praxi je aktivácia hudobných schopností, ktorá prichádza tak prirodzene a nenápadne, ako začína a končí hra. To však neznamená, žeby aktéri didaktickej hry konali neuvedomene, náhodile. Práve naopak, jasný didaktický zámer vytýčený a sledovaný pedagógom je v pozadí každého čiastkového kroku, ba i kroku, ktorý sme pôvodne neplánovali. Úžasné na tom všetkom je to, že sa v podstate všetci hráme.

Ukazuje sa, že najväčším problémom nie je teoretické poznanie problematiky didaktickej hry, ale praktická realizácia a zapájanie hier do vyučovania. Z tohto hladiska možno hovorit' o zvýšených požiadavkách na prípravu učitel'a, o schopnosti organizovat' a správne vyberat' hry. Časté striedanie činnosti pomocou didaktickej hry vnesie do vyučovania radost', chut' pracovat', tvorit a sútažit.

Napokon aj samotný učitel' značne ovplyvní postoj a vztah žiaka k hudobnej náuke. Pedagogické majstrovstvo, premyslený spôsob, správne volené metódy, formy, to všetko je zárukou tvorivej atmosféry celého kolektívu.

\section{Literatura}

Komenský J.A., (1953), Vel'ká didaktika, SPN, Bratislava.

Králiček J., (1976), Hrajme sa s det'mi, SPN, Bratislava.

Laubert J., Laubertová V., (1987), Komenského škola hrou znovu oživená, Štátne pedagogické nakladatel'stvo, Praha.

Otto V., (1988), Slovník náučný (diel), Paseka, Praha.

Průcha J., Wallerová E., Mareš J., (1990), Pedagogický slovník, Portál, Praha.

Šimčík D., (2001), Hudba hrou, Vydavatel'stvo Rokus, Prešov.

Zapletal M., (1986), Organizátor hier, Smena, Bratislava. 